\title{
PUBLICATIONS OF OLLI LEHTO
}

This list includes Lehto's mathematical publications and some articles of general interest for the period 1949-1984. Abbreviations of names of mathematical journals follow guidelines suggested in Chapter 3 of "Mathfile user's guide, Mathematical Reviews online" (American Mathematical Society, Providence, Rhode Island, 1982). Translated titles of articles in Finnish appear in brackets.

1949

Anwendung orthogonaler Systeme auf gewisse funktionentheoretische Extremalund Abbildungsprobleme. Akademische Abhandlung. Helsinki. = Ann. Acad. Sci. Fenn. Ser. A. I. Math.-Phys. 59. 51 pp.

On the existence of analytic functions with a finite Dirichlet integral. Ann. Acad. Sci. Fenn. Ser. A. I. Math.-Phys. 67. 7 pp.

1950

A method of analytic continuation. Ann. Acad. Sci. Fenn. Ser. A. I. Math.-Phys. 70. $11 \mathrm{pp}$.

On Hilbert spaces with a kernel function. Ann. Acad. Sci. Fenn. Ser. A. I. Math.Phys. 74.12 pp.

On the boundary behavior of analytic functions. Proceedings of the International congress of mathematicians, Cambridge, Massachusetts, U.S.A., August 30-September 6, 1950. I. American Mathematical Society, Providence, R. I. pp. 395-396.

Some remarks on the kernel function in Hilbert function space. Ann. Acad. Sci. Fenn. Ser. A. I. Math.-Phys. 109. 6 pp.

On the distortion of conformal mappings with bounded boundary rotation. Commentationes in honorem Pekka Juhana Myrberg die natali eius sexagesimo ediderunt amici et discipuli. Ann. Acad. Sci. Fenn. Ser. A. I. Math.-Phys. 124. 14 pp.

A majorant principle in the theory of functions. Math. Scand. 1. pp. 5-17. Sur la théorie des fonctions méromorphes à caractéristique bornée. C. R. Acad. Sci. Paris 236. pp. 1943-1945.

On meromorphic functions whose values lie in a given domain. Ann. Acad. Sci. Fenn. Ser. A. I. Math.-Phys. 160. 15 pp.

On an extension of the concept of deficiency in the theory of meromorphic functions. Math. Scand. 1. pp. 207-212. 
1954

On meromorphic functions of bounded characteristic. Tolfte skandinaviska matematikerkongressen i Lund 10-15 augusti 1953. Comptes rendus du Douzième congrès des mathématiciens scandinaves tenu à Lund 10-15 août 1953. Lund. pp. $183-187$.

On the distribution of values of meromorphic functions of bounded characteristic. Acta Math. 91. pp. 87-112.

Value distribution and boundary behaviour of a function of bounded characteristic and the Riemann surface of its inverse function. Ann. Acad. Sci. Fenn. Ser. A. I. Math.-Phys. 177.46 pp.

A method in the value distribution theory of meromorphic functions. Proceedings of the International congress of mathematicians 1954, Amsterdam, September 2September 9. II. Erven P. Noordhoff N. V., Groningen/North-Holland Publishing Co., Amsterdam. pp. 131-132.

Boundary theorems for analytic functions. Ann. Acad. Sci. Fenn. Ser. A. I. Math.-Phys. 196. 8 pp. Also included in the volume: Commentationes in honorem Rolf Herman Nevanlinna die natali eius sexagesimo ediderunt amici et discipuli. Helsinki.

On the first boundary value problem for functions harmonic in the unit circle. Ann. Acad. Sci. Fenn. Ser. A. I. Math.-Phys. 210. 26 pp.

- \& K. I. VIRTANEN. Boundary behaviour and normal meromorphic functions. Acta Math. 97. pp. 47-65.

- \& K. I. VIRTANEN. On the behaviour of meromorphic functions in the neighbourhood of an isolated singularity. Ann. Acad. Sci. Fenn. Ser. A. I. Math. 240. 9 pp.

1958

Distribution of values and singularities of analytic functions. Proceedings of the International colloquium on the theory of functions, Helsinki 1957. Ann. Acad. Sci. Fenn. Ser. A. I. Math. 249/3. 16 pp.

A generalization of Picard's theorem. Ark. Mat. 3. pp. 495-500.

Matematiikan tutkimus Suomessa. [Mathematical research in Finland.] Oma maa, Tietokirja Suomen kodeille. Kolmas osa, Maaliskuu. Werner Söderström Osakeyhtiö, Porvoo - Helsinki. pp. 110-120. 
The spherical derivative of meromorphic functions in the neighbourhood of an isolated singularity. Comment. Math. Helv. 33. pp. 196-205.

F. W. GeHring \& - On the total differentiability of functions of a complex variable. Ann. Acad. Sci. Fenn. Ser. A. I. Math. 272. 9 pp.

- \& K. I. VirTANEN \& JuSSI VÄISÄLÄ. Contributions to the distortion theory of quasiconformal mappings. Ann. Acad. Sci. Fenn. Ser. A. I. Math. 273. 14 pp.

1960

On the differentiability of quasiconformal mappings with prescribed complex dilatation. Ann. Acad. Sci. Fenn. Ser. A. I. Math. 275. 28 pp.

- \& K. I. VIRTANEN. On the existence of quasiconformal mappings with prescribed complex dilatation. Ann. Acad. Sci. Fenn. Ser. A. I. Math. 274. 24 pp.

1961

Matematiikan nykyiselle tutkimukselle olennaisista piirteistä. [On aspects of current mathematical research.] Valvoja 81, Helsinki. pp. 147-152.

1965

An extension theorem for quasiconformal mappings. Papers presented to J. E. Littlewood on his 80th birthday. Proc. London Math. Soc. (3) 14A. pp. 187-190.

Remarks on the integrability of the derivatives of quasiconformal mappings. Ann. Acad. Sci. Fenn. Ser. A. I. Math. 371. 8 pp.

- \& K. I. Virtanen. Quasikonforme Abbildungen. Die Grundlehren der mathematischen Wissenschaften in Einzeldarstellungen mit besonderer Berücksichtigung der Anwendungsgebiete 126. Springer-Verlag, Berlin-HeidelbergNew York. XI+269 pp.

1966

A boundary value problem for conformal mappings. Современные проблемы теории аналитических функций. Международная конференция по теории аналитических функций, Ереван, 1965 г. Издательство «Наука», Москва. pр. $216-218$.

Homeomorphic solutions of a Beltrami differential equation. Festband zum 70. Geburtstag von Rolf Nevanlinna. Vorträge, gehalten anläßlich des Zweiten Rolf Nevanlinna -Kolloquiums in Zürich vom 4.-6. November 1965. Springer-Verlag, Berlin-Heidelberg-New York. pp. 58-65.

Kvasikonformikuvausten teorian kehityksestä. Summary: On the development of the theory of quasiconformal mappings. Arkhimedes 1966:2. pp. 23-30. 
1968

Quasiconformal mappings in the plane. Труды Международного конгресса математиков (Москва - 1966). Proceedings of International congress of mathematicians (Moscow - 1966). ... Издательство «Мир», Москва. pp. 319-322. [Already included in the volume: Тезисы докладов по приглашению. Международный конгресс математиков. Abstracts of reports on invitation. International congress of mathematicians. ... Москва, 1966, pp. 68-71.]

1969

Reaalifunktioiden teoria. [The theory of real functions.] Limes ry, Helsinki. 4+97 pp.

Suomen matemaattinen yhdistys 100 vuotta. [The Finnish mathematical society 100 years.] Arkhimedes 1969:1. pp. 1-4.

1970

Homeomorphisms with a given dilatation. Proceedings of the 15th Scandinavian congress, Oslo 1968. Lecture Notes in Mathematics 118. Springer-Verlag, BerlinHeidelberg-New York. pp. 58-73.

Entwicklung der Theorie quasikonformer Abbildungen. Mitt. Math. Ges. DDR 1970:3-4. pp. 36-47.

Riemann surfaces. Notes of lectures given at the University of Minnesota, winter and spring quarters, 1968. University of Minnesota, Institute of Technology, School of Mathematics, Minneapolis, Minnesota 55455. IV+113 pp.

Matematiikan peruskäsitteistä. [Basic concepts of mathematics.] Suomalainen Tiedeakatemia. Esitelmät ja pöytäkirjat 1969. Helsinki. pp. 159-171.

Differentiaali- ja integraalilaskenta II. [Differential and integral calculus II.] Helsinki. $4+113$ pp.

P. L. DUREN \& -. Schwarzian derivatives and homeomorphic extensions. Ann. Acad. Sci. Fenn. Ser. A. I. Math. 477. 11 pp.

Remarks on generalized Beltrami equations and conformal mappings. Proceedings of the Romanian-Finnish seminar on Teichmüller spaces and quasiconformal mappings, Braşov, Romania, 1969. Volume dedicated to the memory of E. Lindelöf and S. Stoillow. Publishing House of the Academy of the Socialist Republic of Romania, Bucureşti. pp. 203-214.

Schlicht functions with a quasiconformal extension. Ann. Acad. Sci. Fenn. Ser. A. I. Math. 500. 10 pp.

Differentiaali- ja integraalilaskenta III. [Differential and integral calculus III.] Limes ry, Helsinki. 6+178 pp. 
1973

Conformal mappings and Teichmüller spaces. [Lecture notes.] Technion - Israel Institute of Technology, Department of Mathematics, Haifa, Israel. II+58 pp.

Matematiikka ja käytäntö. [Mathematics and applications.] TTA. Tutkimus ja tekniikka - Forskning och teknik 1973:3. Teknillisten tieteiden akatemia - Akademin för tekniska vetenskaper r.y., Helsinki. pp. 36-40.

- \& K. I. VirTANEN. Quasiconformal mappings in the plane. Second edition. Translated from the German by K. W. LuCAs. Die Grundlehren der mathematischen Wissenschaften in Einzeldarstellungen mit besonderer Berücksichtigung der Anwendungsgebiete 126. Springer-Verlag, Berlin-Heidelberg-New York. VIII+258 pp. ISBN 3-540-06093-6.

\section{4}

Group isomorphisms induced by quasiconformal mappings. Contributions to analysis. A collection of papers dedicated to Lipman Bers. Academic Press, New York-London. pp. 241-244.

Mittaamisen probleemasta. Summary: On the notion of measure. Arkhimedes 26. pp. 7-11.

\section{5}

F. W. GeHring \& - Lectures on quasiconformal mappings. (Part I. Quasiconformal mappings in the plane by OLLI LeHTO. Part II. Quasiconformal mappings in $R^{n}$ by F. W. Gehring.) Lecture Note 14. University of Maryland, Department of Mathematics, College Park, Maryland. II+110 pp. (pp. 1-43, 44-100.)

1976

Quasiconformal mappings and singular integrals. Trasformazioni quasiconformi e questioni connesse, 12-15 marzo 1974. Symposia Mathematica 18. Istituto Nazionale di Alta Matematica. Academic Press, London-New York. pp. 429-453.

On univalent functions with quasiconformal extensions over the boundary. J. Analyse Math. 30, Honoring Max M. Schiffer on his sixty-fifth birthday. pp. 349354.

- \& Olli TAMmi. Area method and univalent functions with quasiconformal extensions. Commentationes in honorem Rolf Nevanlinna LXXX annos nato. Ann. Acad. Sci. Fenn. Ser. A. I. Math. 2. pp. 307-313.

1977

Analytic families of quasi-conformal mappings. Proceedings of the Sixth conference on analytic functions, Kraków, September 4-11, 1974. Ann. Polon. Math. 33, 1976/1977. pp. 57-62. 
Quasiconformal homeomorphisms and Beltrami equations. Discrete groups and automorphic functions. Proceedings of an instructional conference organized by the London Mathematical Society and the University of Cambridge (a NATO advanced study institute). Academic Press, London-New York-San Francisco. pp. $121-142$.

Domain constants associated with Schwarzian derivative. Comment. Math. Helv. 52. pp. 603-610.

Integraali kautta aikojen. Summary: Integral throughout the ages. Arkhimedes 29. pp. $67-72$.

1978

Univalent functions and Teichmüller theory. Proceedings of the First FinnishPolish summer school in complex analysis at Podlesice. I. Informal lectures. University of Lódź, Lódź. pp. 11-33.

Value distribution of meromorphic functions. Proceedings of the Rolf Nevanlinna symposium on complex analysis, Silivri 1976. Publication of the Mathematical Research Institute, Istanbul 7. İstanbul. pp. 37-45.

Application of singular integrals to extremal mappings of Riemann surfaces. Комплексный анализ и его приложения. Сборник статей Посвящается академику Илье Несторовичу Векуа к его семидесятилетию. Академия Наук СССР, Ордена Ленина Математический Институт имени В. А. Стеклова. Издательство «Наука», Москва. pp. 336-341.

Univalent functions, Schwarzian derivatives and quasiconformal mappings. Enseignement Math. (2) 24. pp. 203-214. Included also in the volume: Contributions to analysis. Papers communicated to an international symposium on analysis held on April 10-15, 1978 at the Eidgenössische Technische Hochschule Zürich in honour of Professor Albert Pfluger. Monographie 27 de l'Enseignement Mathématique. Université de Genève, 1979. pp. 73-84.

Matematiikan tutkimuksen nykyvaiheista. [Mathematical research today.] Suomen tieteen ulottuvuuksia, Tieteen päivät 10-12. 1. 1977. Taskutieto 145. Werner Söderström Osakeyhtiö, Porvoo-Helsinki-Juva. pp. 389-396. ISBN 951-0-08938-9.

1979

On the boundary value problem for quasiconformal mappings. Romanian-Finnish seminar on complex analysis, Proceedings, Bucharest, Romania, June 27-July 2, 1976. Lecture Notes in Mathematics 743. Springer-Verlag, Berlin-HeidelbergNew York. pp. 184-196.

Remarks on Nehari's theorem about the Schwarzian derivative and schlicht functions. J. Analyse Math. 36, Dedicated to the memory of Zeev Nehari. pp. 184190. 
- \& Olli TAmmi. Schwarzian derivative in domains of bounded boundary rotation. Ann. Acad. Sci. Fenn. Ser. A. I. Math. 4, 1978/1979. pp. 253-257.

1980

Universal Teichmüller space. Vorlesung gehalten im Sommersemester $1980 \mathrm{im}$ Rahmen des Nachdiplomstudiums des Mathematik-Departments ETH Zürich. Eidgenössische Technische Hochschule Zürich, Forschungsinstitut für Mathematik, Zürich. $2+57$ pp.

Funktioteoria I-II. [Theory of functions I-II.] Limes ry, Helsinki. 185 pp.

1982

On the birth of the Nevanlinna theory. Commentationes in memoriam Rolf Nevanlinna. Ann. Acad. Sci. Fenn. Ser. A. I. Math. 7:1. pp. 5-23.

Nevanlinnan arvojenjakautumisoppi. [A historical survey of Nevanlinna theory for meromorphic functions.] Arkhimedes, Rolf Nevanlinna -erikoisnumero, Rolf Nevanlinna special issue. pp. 15-29.

Matematiikka, a young man's game. [Mathematics, a young man's game.] Kutsu Filosofisen tiedekunnan maisteri- ja tohtoripromootioon toukokuun 28. päivänä 1982. Inbjudan till Filosofiska fakultetens magister- och doktorspromotion den 28 maj 1982. Helsinki. pp. 5-10.

1983

On Rolf Nevanlinna's mathematical work and on his role, together with Simion Stoilow, as a promotor of Romanian-Finnish mathematical relations. Complex analysis - Fifth Romanian-Finnish seminar. Proceedings of the Seminar held in Bucharest, June 28-July 3, 1981. Part 1. Lecture Notes in Mathematics 1013. Springer-Verlag, Berlin-Heidelberg-New York-Tokyo. pp. 1-7.

1984

Some recent developments in the theory of Teichmüller spaces. Международная конференция по аналитическим методам в теории чисел и анализе, Москва, 14-19 сентября 1981 г. Труды Мат. Инст. Стеклов. [Trudy Mat. Inst. Steklov.] 163, pp. 143-146.

$A$ historical survey of quasiconformal mappings. Zum Werk Leonhard Eulers. Vorträge des Euler-Kolloquiums im Mai 1983 in Berlin. Birkhäuser Verlag, BaselBoston-Stuttgart. pp. 205-217. ISBN 3-7643-1609-8. 